\title{
Terrestrial Reserve Networks Do Not Adequately Represent Aquatic Ecosystems
}

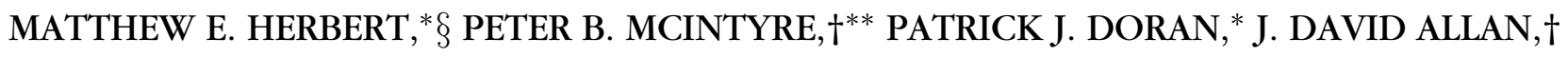 \\ AND ROBIN ABELL
}

${ }^{*}$ The Nature Conservancy, 101 East Grand River Avenue, Lansing, MI 48906-4374, U.S.A.

†School of Natural Resources and Environment, University of Michigan, Ann Arbor, MI 48109, U.S.A.

$\neq$ World Wildlife Fund-United States, $125024^{\text {th }}$ Street NW, Washington, D.C. 20037, U.S.A.

\begin{abstract}
Protected areas are a cornerstone of conservation and have been designed largely around terrestrial features. Freshwater species and ecosystems are bighly imperiled, but the effectiveness of existing protected areas in representing freshwater features is poorly known. Using the inland waters of Michigan as a test case, we quantified the coverage of four key freshwater features (wetlands, riparian zones, groundwater recharge, rare species) within conservation lands and compared these with representation of terrestrial features. Wetlands were included within protected areas more often than expected by chance, but riparian zones were underrepresented across all (GAP 1-3) protected lands, particularly for beadwater streams and large rivers. Nevertheless, within strictly protected lands (GAP 1-2), riparian zones were highly represented because of the contribution of the national Wild and Scenic Rivers Program. Representation of areas of groundwater recharge was generally proportional to area of the reserve network within watersheds, although a recharge hotspot associated with some of Michigan's most valued rivers is almost entirely unprotected. Species representation in protected areas differed significantly among obligate aquatic, wetland, and terrestrial species, with representation generally bighest for terrestrial species and lowest for aquatic species. Our results illustrate the need to further evaluate and address the representation of freshwater features within protected areas and the value of broadening gap analysis and other protected-areas assessments to include key ecosystem processes that are requisite to long-term conservation of species and ecosystems. We conclude that terrestrially oriented protected-area networks provide a weak safety net for aquatic features, which means complementary planning and management for both freshwater and terrestrial conservation targets is needed.
\end{abstract}

Keywords: fish conservation, freshwater conservation, groundwater, insect conservation, mollusk conservation, protected areas, riparian, wetlands

Las Redes de Reservas Terrestres no Representan a los Ecosistemas Acuáticos Adecuadamente

Resumen: Las áreas protegidas son una piedra angular de la conservación y han sido diseñadas principalmente alrededor de atributos terrestres. Las especies y ecosistemas dulceacuícolas se encuentran en peligro, pero la efectividad de las áreas protegidas existentes para representar las características dulceacuícolas es poco conocida. Utilizando las aguas interiores de Michigan como un caso de prueba, cuantificamos la cobertura de cuatro atributos dulceacuícolas clave (bumedales, zonas ribereñas, recarga de agua subterránea y especies raras) en las tierras conservadas y las comparamos con la representación de los atributos terrestres. Los bumedales estaban incluidos en las áreas protegidas más a menudo que lo esperado por azar, pero las zonas ribereñas estuvieron insuficientemente representadas en todas las tierras protegidas (GAP1-3), particularmente en manantiales y ríos grandes. Sin embargo, las zonas ribereñas estuvieron bien representadas en las tierras con protección estricta (GAP 1-2) debido a la contribución del Programa Nacional de Ríos Silvestres y Escénicos. La representación de áreas de recarga de aguas subterráneas generalmente fue

§email mberbert@tnc.org

** Current Address: Center for Limnology, University of Wisconsin-Madison, 680 N. Park, Madison, WI 53706, U.S.A. Paper submitted March 23, 2009; revised manuscript accepted October 20, 2009.

\section{2}


proporcional al área de la red de reservas dentro de cuencas hidrologicas, aunque un sitio importante de recarga asociado con algunos de los ríos más valiosos en Michigan estaba casi totalmente desprotegido. La representación de especies en áreas protegidas difirió significativamente entre las especies acuáticas obligadas, de humedales y terrestres, con una representación generalmente mayor para las especies terrestres y menor para las acuáticas. Nuestros resultados ilustran la necesidad de evaluar y atender la representación de los atributos dulceacuícolas dentro de las áreas protegidas y el valor de ampliar el análisis de brechas y otras evaluaciones de áreas protegidas para incluir los procesos ecosistémicos claves que son requisito para la conservación a largo plazo de especies y ecosistemas. Concluimos que las redes de áreas protegidas orientadas al medio terrestre proporcionan una red de seguridad débil para los atributos acuáticos, lo que significa que se requiere planeación y manejo complementario tanto para objetivos de conservación dulceacuícolas como terrestres.

Palabras Clave: agua subterránea, áreas protegidas, conservación de agua dulce, conservación de insectos, conservación de moluscos, humedales, ribereño

\section{Introduction}

There is ample evidence of the imperiled state of freshwater biodiversity, habitats, and ecosystems (Allan \& Flecker 1993; Ricciardi \& Rasmussen 1999; Dudgeon et al. 2006), yet terrestrial conservation features have received far more attention and resources when designating protected areas (Abell et al. 2007). Freshwater ecosystems are heavily influenced by adjacent terrestrial ecosystems; therefore, land-based conservation measures can provide some protection to rivers and lakes (Saunders et al. 2002; Mancini et al. 2005). Nevertheless, the effectiveness of such incidental protection for conserving important freshwater features remains uncertain. Assessing the spatial extent of both intentional and incidental representation of freshwaters within protected areas is a prerequisite for identifying and filling protection gaps-a priority of the Ramsar Convention on Wetlands of International Importance (Ramsar Bureau 2009) and the Convention on Biological Diversity (2006).

Globally, protected areas cover $12 \%$ of the nonmarine surface of the Earth. The World Database on Protected Areas (WDPA 2004) suggests that the world's 426 freshwater ecoregions (Abell et al. 2008) range from totally unprotected to completely covered, with an average of $13 \%$ surface area of freshwater ecoregions protected and nearly two-thirds falling below that number (WDPA 2004; see Supporting Information). It is unclear, however, how to interpret these findings. Assessing the degree to which terrestrial reserves confer protection to freshwater ecosystems is complicated by the interconnected nature of aquatic ecosystems, the critical role of hydrological dynamics, and the poor state of spatial data describing freshwater ecosystems and species (Abell et al. 2007). Global-scale analyses conducted without the benefit of data on specific freshwater conservation features can hardly begin to address these complexities.

We tested the hypothesis that freshwater and terrestrial features are equally represented within protected lands. We focused on the state of Michigan, which is located at the heart of the North American Great Lakes region and includes $>11,000$ lakes and $>90,000 \mathrm{~km}$ of streams. The state contains a relatively large network of protected areas covering $21.8 \%$ of its land area (Fig. 1). This is three times the proportion of area protected in the broader Great Lakes freshwater ecoregion (Abell et al. 2008), and represents a greater proportion of protected area than occurs in $62 \%$ and $84 \%$ of freshwater ecoregions in the United States and worldwide, respectively (Supporting Information).

The makeup of Michigan's protected areas is typical of that seen throughout the United States (Dietz \& Czech 2005); most areas are managed for multiple uses. Land use in Michigan is also representative of much of North America; forested areas predominate in northern Michigan and more agricultural and urban land uses predominate in southern Michigan. A wide variety of high-quality spatial data are available for Michigan. We focused on data-rich wetland and riverine habitats and excluded lake features for which our methods were less appropriate.

We evaluated the degree to which three coarse-filter freshwater targets (wetlands, river riparian zones, and groundwater recharge) and one fine-filter target (rare species) were represented within protected areas (Noss 1987). Wetlands provide essential habitat and help regulate the functions of river systems (Miller \& Nudds 1996). Draining, filling, and contamination continue to reduce wetland area and condition worldwide (Dahl 1990; Mitsch \& Gosselink 2007). Riparian zones along rivers protect stream habitat, stabilize banks, and provide organic matter and habitat-forming wood (Gregory et al. 1991; Allan \& Castillo 2007). Riparian buffers are routinely specified in land-management plans for the protection of aquatic habitats (e.g., FEMAT 1993) and are the focus of Michigan's Natural Rivers Program, the state's only protected-areas program specifically designed for inland waters. Groundwater recharge is requisite to maintaining natural stream flow, temperature, and chemistry, and thus to conserving stream biota (Poff et al. 1997; Zorn et al. 2002). Michigan recently enacted legislation to regulate groundwater withdrawals to prevent reductions in stream flow and subsequent "adverse resource 


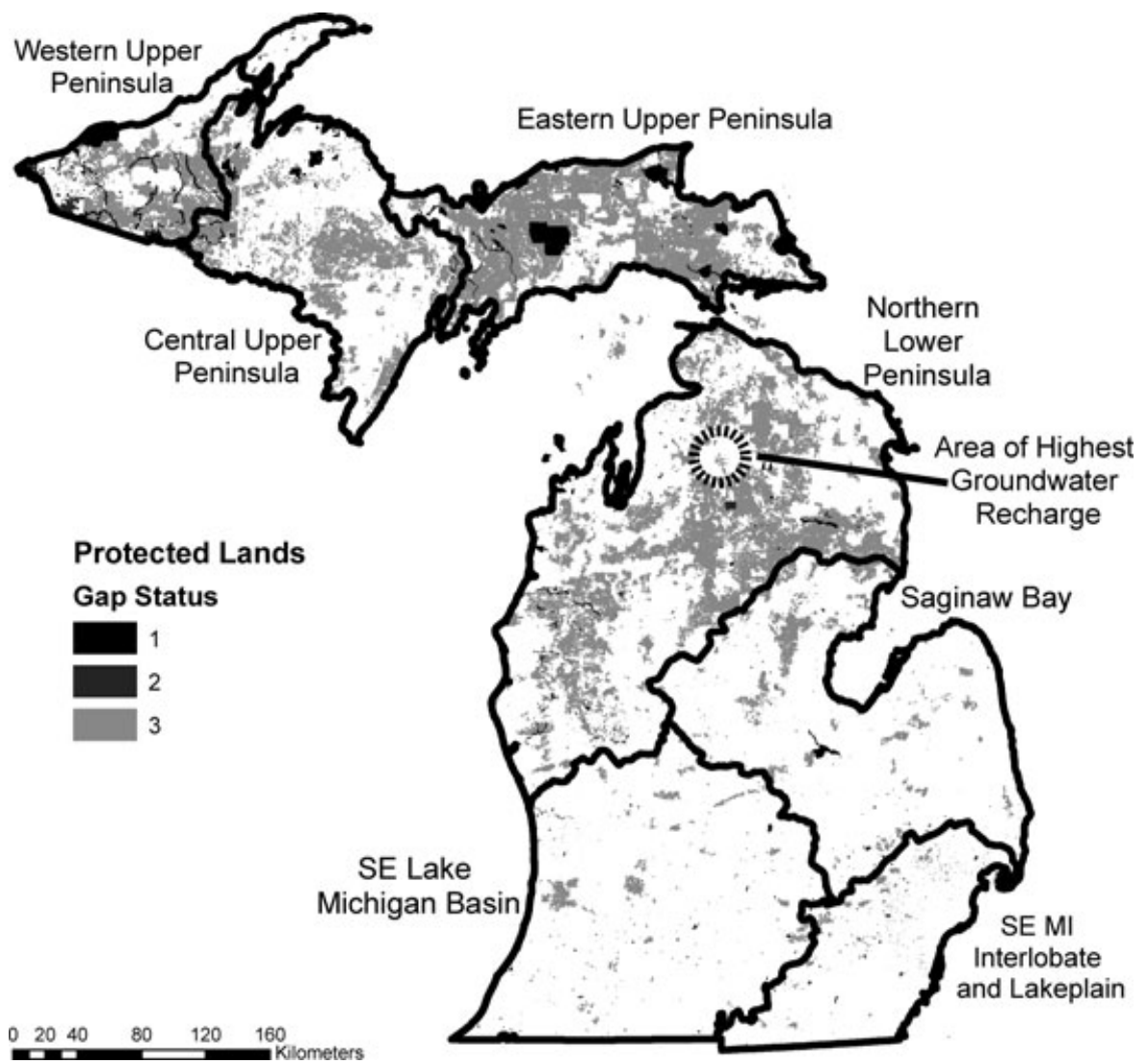

Figure 1. Protected lands in Michigan, including federal, state, municipal, and nongovernmental organization lands (Conservation and Recreational Lands database) (GAP status: 1, permanently protected and managed to maintain ecosystem structure and function, includes wilderness areas, Nature Conservancy preserves, and national lakeshores; 2, permanently protected and managed primarily to maintain land in its natural state, although some degradation is possible, includes some state parks and national forest special management areas; 3, permanently protected but subject to low-intensity or localized extractive uses, includes national forest, state forest, and state game areas). Dark borders denote the seven ecological drainage units of Michigan.

impacts" (Michigan Public Acts 179-190 of 2008). Finally, protecting rare species is often a central motivation for conservation efforts, and is necessary because these fine-filter components of biological communities often require specific attention to ensure their conservation (Noss 1987). Evaluations of freshwater protection rarely include ecosystem processes such as groundwater recharge, despite increasing recognition that long-term conservation strategy requires their conservation.

Given that aquatic and terrestrial features are not independent (Wuethrich 2000), well-planned protected areas might be expected to represent both ecosystem types. Our aim was to elucidate whether freshwater features are proportionately represented within Michigan's protected areas. We used the proportion of terrestrial land area or species ranges encompassed within protected areas as a benchmark against which to judge representation of aquatic features. Using Michigan as a test case, our overarching goal was to inform the larger question of how well the world's protected-area systems capture freshwaters and their imperiled biodiversity.

\section{Methods}

To characterize the representation of Michigan's freshwater features across the protected lands network of the state (excluding Great Lakes islands), we used the Conservation and Recreational Lands (CARL) database (Fig. 1.; DU and TNC 2007). For Michigan, CARL is the most comprehensive database of conservation-oriented land, and it includes the established GAP designations used in the Gap Analysis Program (Scott et al. 1993). Herein, we refer to areas classified as GAP status 1-3 as protected and as GAP status 1-2 as strictly protected. Each status level connotes a different degree of conservationoriented management: GAP 1, full protection of biodiversity and ecosystem functioning; GAP 2, maintenance of natural conditions; GAP 3, "multiple use," including localized resource extraction. Although GAP 3 lands are managed for diverse purposes that sometimes conflict with conservation goals, they were essential to our analysis because they represent such a large majority of protected areas in the United States that conserving aquatic biodiversity without them would be unlikely (Scott et al. 2001).

Using a geographic information system (GIS) (ArcMap, version 9.2, ESRI, Redlands, California), we overlaid protected lands on a suite of aquatic features. We evaluated the degree of representation at multiple spatial scales, including statewide, by ecological drainage unit (EDU) (Fig. 1), and for rare species at local and landscape scales. The EDUs (mean size $21,198 \mathrm{~km}^{2}$, range 9021-38,296 $\mathrm{km}^{2}$ ) are hydroecological subregions used to stratify conservation goals for freshwater biodiversity representation 

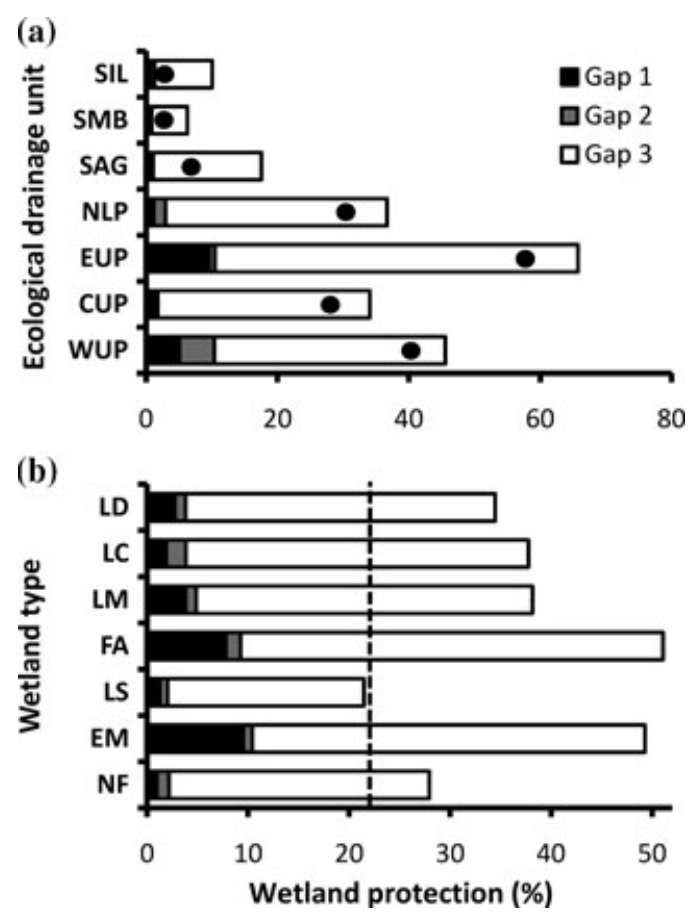

Figure 2. Level of protection of wetland habitats in Michigan for (a) ecological drainage units and (b) particular wetland types (SIL, southeastern interlobate and lake plain; SMB, soutbeastern Lake Michigan basin, SAG, Saginaw Bay; NLP, nortbern lower peninsula; CUP, EUP, and WUP, central, eastern, and western Upper Peninsula respectively; black circles indicate the percentage of each drainage unit within protected areas (GAP 1-3); LD, lowland deciduous forest; LC, lowland coniferous forest; LM, mixed lowland forest; FA, floating aquatic vegetation; LS, lowland shrub; EM, emergent vegetation; NF, mixed nonforest; dashed line, overall percentage [21.8\%] of land statewide within protected areas). See Fig. 1 for definition of different levels of GAP status.

(The Nature Conservancy 2001). They provided large, ecologically meaningful units for evaluation of regional differences in protection levels.

We assessed representation of wetlands within protected areas statewide and within EDUs. Wetland distributions were based on wetland land-cover types (30-m resolution) designated by the Michigan Department of Natural Resources (2003). Although these categorizations are somewhat coarse, they were the best available statewide data and they directly related to current management efforts. For both protected (GAP 1-3) and strictly protected (GAP 1-2) lands, we used a paired $t$ test to determine whether the proportion of wetlands within protected areas differed from the overall proportion of protected area within EDUs. We also compared statewide coverage of each of seven wetland types (Fig. 2) with the statewide proportion of protected area. Because wetland loss has been extensive in Michigan, as in the United States generally (Dahl 1990), we repeated the analysis of wetland protection status by EDU with wetland distributions circa 1800 (Comer et al. 1995).

To evaluate riparian protection, we used the National Hydrography Datalayer (NHD) (1:100,000 scale; U.S. Geological Survey 1999) for Michigan combined with a Michigan hydrography polygon layer (MCGI 2007) in which the width of wider stream reaches (generally streams $>4$ th order) was derived more precisely. A 100-m riparian buffer was added to each stream, creating a set of stream-riparian polygons. Selection of a 100-m buffer width is consistent with the benchmark Northwest Forest Plan Standards and Guidelines and emphasizes the importance of riparian protection for preventing bank erosion and protecting fish habitat (Olson et al. 2007). We quantified the proportion of riparian buffer area in both protected and strictly protected lands for each stream order. The proportions of riparian and total area protected were compared across EDUs with a paired $t$ test. Across stream orders, we used a $t$ test to compare riparian representation with the proportion of land area protected statewide. Finally, we evaluated riparian representation for the 16 National Wild and Scenic Rivers and 16 Michigan Natural Rivers.

We evaluated representation of groundwater resources within protected areas with a groundwater-recharge map (1.6-km resolution) developed by the U.S. Geological Survey (Aichele 2005). The map was based on estimated groundwater recharge rates from regression models describing observed stream baseflow as a function of geology, precipitation, and current land use. Although all natural lands within the state have some recharge value, areas with higher recharge rates provide a larger proportion of groundwater contribution to aquatic systems. We compared the proportion of total land area and total groundwater recharge within protected areas at three hierarchical spatial scales: statewide, EDU, and hydrologic units. For hydrologic units, we used eight-digit hydrologic unit code watersheds ( $n=52$; mean area $=2760 \mathrm{~km}^{2}[\mathrm{SE}$ 201]) (hereafter, HUC 8 watersheds), which were derived by the U.S. Geological Survey, who divided hydrologic units into successively smaller units at 1:24,000 scale; the HUC 8 watersheds are the fourth level of division (Seaber et al. 1987). We selected HUC 8 rather than smaller HUC 12 watersheds for this analysis because complex flow paths are likely to integrate infiltrating groundwater at relatively broad spatial scales. The significance of differences in protection of land and groundwater recharge was tested separately at the EDU and watershed scales with paired $t$ tests.

To evaluate representation of rare species, we used the Natural Heritage Biotics Database compiled by the Michigan Natural Features Inventory (MNFI 2008). Within this database, species occurrences are available as polygons (e.g., a $2-\mathrm{km}$ reach of stream) that represent the 
localized area a population may occupy on the basis of observed distribution, available habitat, and the life history and mobility of the species. We limited analyses to globally rare (G1-G3) animal species (Supporting Information) and eliminated populations not verified since 1983 . Aquatic species were defined as those that live entirely under water for at least a portion of their life.

We assessed representation of rare aquatic, wetland, and terrestrial upland species within GAP 1-3 protected areas at two scales, local and landscape. We refer to both watershed-based (for aquatic species) and nonwatershedbased (for terrestrial species) analyses as landscape analyses because of the relatively large spatial scales involved. At the local scale, we added a 100-m riparian buffer to each population polygon for aquatic species to yield a mean area of 100.1 ha $(n=16, \mathrm{SE}=36.9)$ across species. Population polygons for wetland and terrestrial species were comparable in size to buffered aquatic species polygons. At the landscape scale, we used HUC 12 units to delimit watersheds containing rare aquatic species. These watersheds had an average area of $82.4 \mathrm{~km}^{2}(n=16$ [SE 2.93]). For wetland and terrestrial species, we designated a circular buffer area around each population polygon that was equivalent to the mean HUC 12 watershed area in Michigan. At both local and landscape scales, we quantified the percentage of each population polygon (with or without buffer, as appropriate) that was within GAP 1-3 lands and averaged this percentage across populations of each species.

To compare levels of protection among aquatic, wetland, and terrestrial species, we evaluated the proportion of populations in each species that were relatively well protected or virtually unprotected. On the basis of natural breaks in the distribution of protection levels across all populations, we selected $95 \%$ and $70 \%$ as thresholds for well-protected status at the local and landscape scales, respectively. Again on the basis of natural breaks in the data, populations with $<20 \%$ or $10 \%$ coverage in protected areas were considered virtually unprotected at the local and landscape scales. For each species, we calculated the proportion of populations considered well protected or unprotected and then compared these proportions among terrestrial, wetland, and aquatic species with one-way analysis of variance (ANOVA) with species as replicates. Separate analyses were conducted for well-protected and unprotected classes. We transformed proportions to the arcsine square root and used Tukey's HSD (honestly significantly different) for post hoc pairwise comparisons $(\alpha=0.05)$.

\section{Results}

Wetlands made up nearly $20 \%$ of Michigan's current land cover. Within EDUs, the proportion of wetland area protected significantly exceeded the total proportion of area protected in GAP $1-3$ lands $\left(t_{6}=7.74, p<0.001\right)$ and was marginally significant for GAP 1-2 $\left(t_{6}=2.38, p<\right.$ $0.054)$. For example, $58 \%$ of the total area and $65 \%$ of wetland area in the EDU of the eastern Upper Peninsula was in GAP 1-3 lands (Fig. 2a). In the EDU of the more heavily populated southeastern Lake Michigan, $7 \%$ of the wetland area lies in GAP $1-3$, whereas only $1 \%$ of the total land area is in GAP 1-3. With data from circa 1800 , wetlands were better represented than expected within EDUs for GAP $1-3$ lands $\left(t_{6}=6.10, p<0.001\right)$, but representation for GAP 1-2 lands did not differ $\left(t_{6}=1.75\right.$, $p<0.130$ ).

Average representation of each type of wetland also exceeded null expectations for GAP $1-3$ lands $\left(t_{6}=3.83\right.$, $p=0.009$ ) and for GAP 1-2 lands (marginally significant at $t_{6}=2.40, p=0.053$ ). Of the seven major wetland types within Michigan, only lowland shrub wetland was slightly underrepresented (Fig. 2b). Eighty-seven percent of the area of Michigan's protected wetlands was on GAP 3 lands.

The proportion of riparian area within GAP 1-3 lands (16.2\%) was substantially lower than total area in GAP 1-3 lands (21.8\%), and the difference was significant across EDUs $\left(t_{6}=-2.51, p=0.049\right.$; Fig. $\left.3 \mathrm{~b}\right)$. The disparity was greatest in the northern Lower Peninsula and throughout the Upper Peninsula. Similarly, riparian representation within GAP 1-3 lands was lower than expected across stream orders $\left(t_{6}=-2.90, p=0.027\right.$; Fig. 3a). Riparian representation was particularly weak for headwater streams (first through third order), which accounted for $87 \%$ of stream length in Michigan, and for the largest rivers. Eighty-two percent of Michigan's protected riparian area was on GAP 3 lands.

GAP 1-2 lands (2.2\% of Michigan's land area) and land in the Michigan Natural Rivers program yielded a somewhat different perspective on riparian protection. Riparian zones were more likely to be included in GAP 1-2 areas than expected by chance across EDUs $\left(t_{6}=2.54, p=0.044\right)$ and across stream orders $\left(t_{6}=2.68\right.$, $p=0.036$ ). This much higher level of protection for GAP 1-2 lands was due to the 16 rivers designated as national wild and scenic, which make up $46.5 \%$ of the riparian GAP 1-2 lands in the state. With these lands removed, the proportion of riparian lands represented within GAP 1-2 was lower than the proportion of GAP 1-2 lands statewide, with no significant differences across EDUs $\left(t_{6}=-1.01, p=0.352\right)$. Designation as a state natural river provided riparian protection to an additional $0.7 \%$ of Michigan's area, representing a $4.3 \%$ increase in the total area of protected riparian buffers. The contribution of state natural rivers was greatest in the northern Lower Peninsula, where they covered $2.7 \%$ of EDU area and enhanced riparian protected area by $10.6 \%$. In the southeast Lake Michigan basin EDU, areas designated as natural rivers covered $0.5 \%$ and resulted in a $14.6 \%$ increase in riparian protection. 

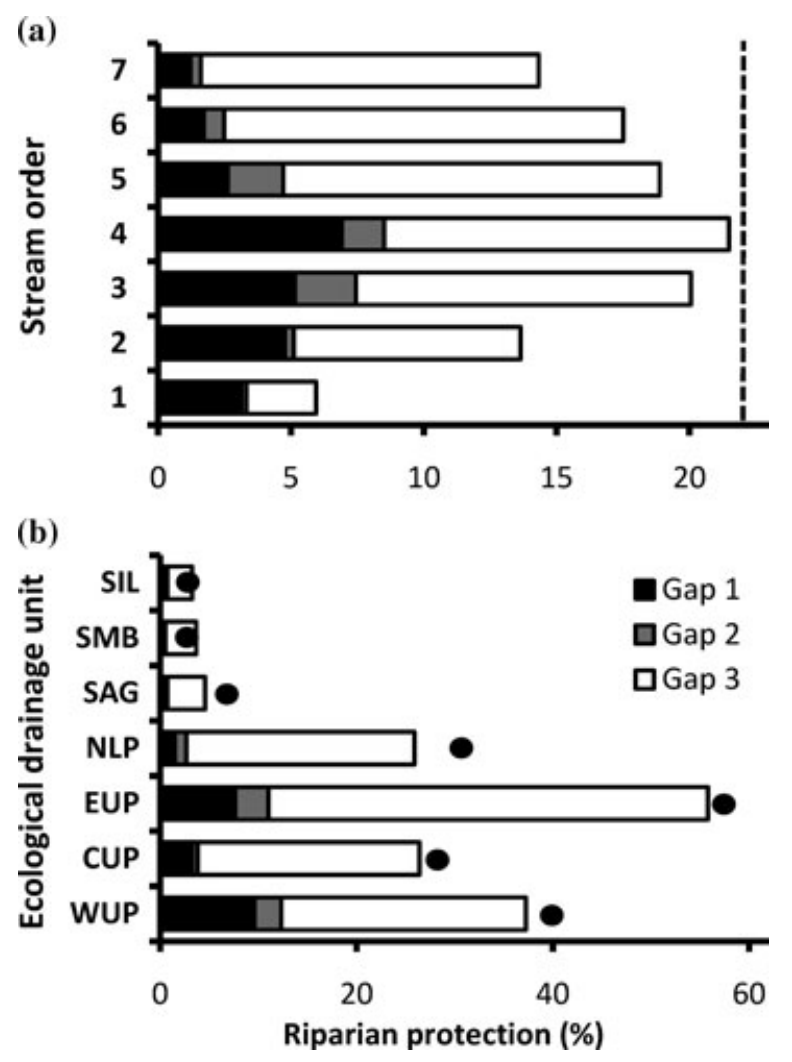

Figure 3. Protection of riparian babitat $(<100 \mathrm{~m}$ from stream) in Michigan for (a) stream order and (b) ecological drainage unit (dashed line, overall percentage [21.8\%] of land statewide within protected areas [GAP 1-3]; black circles indicate the overall percentage of land in a drainage unit that is protected). See Fig. 2 for definitions of drainage-unit initializations and Fig. 1 for definitions of GAP status.

Protected areas generally featured above-average recharge rates (Fig. 4); 25.8\% of statewide recharge occurred in the $22 \%$ of Michigan within GAP 1-3 areas. Nevertheless, across EDUs the proportion of land area and groundwater recharge protected did not differ $\left(t_{6}=0.62\right.$, $p=0.558)$. Recharge representation was lower than land protection only in the sparsely populated western and central Upper Peninsula. At the watershed scale (HUC 8), a higher proportion of recharge than land area was protected $\left(t_{52}=4.02, p<0.001\right)$, indicating that GAP 1-3 areas have higher recharge rates than unprotected lands. The absolute difference was small, rarely exceeding 3\%. The highest groundwater recharge rates in Michigan were concentrated in a $300-\mathrm{km}^{2}$ area near Gaylord that is almost entirely outside the current protected area network (Fig. 1).

More than $90 \%$ of local populations of rare fishes and aquatic mollusks were virtually unprotected at the local scale (Supporting Information). Protection levels for insects were generally highest; among the five rare species

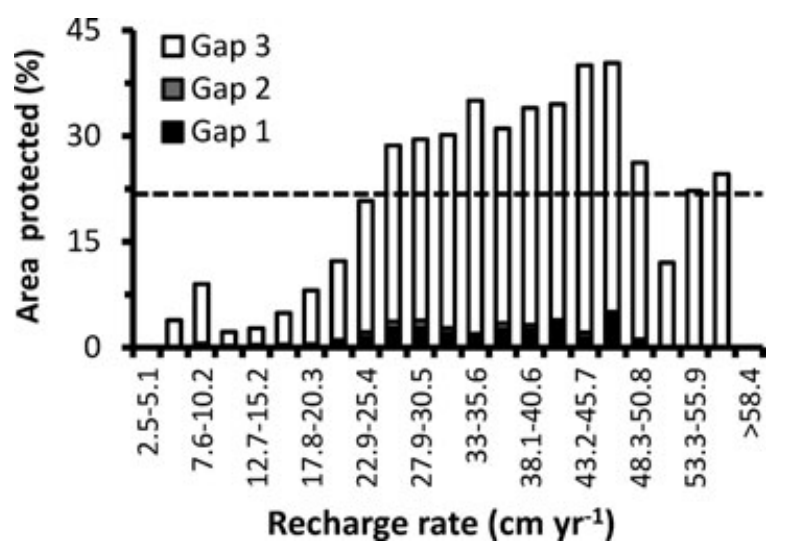

Figure 4. Land-protection levels relative to groundwater recharge rates in Michigan. Bars represent the proportion of pixels with a given recharge rate that are designated for conservation (GAP 1-3) (GAP status defined in Fig. 1; dasbed line, overall percentage [21.8\%] of land statewide within protected areas [GAP 1-3]).

of insects, half the populations fell at least 50\% within protected areas. In contrast, nine of the 11 rare fishes and mollusks had no highly protected populations at the local scale. Every population of eastern sand darter (Etbeostoma pellucidum), pygmy snaketail (Opbiogomphus bowei), purple lilliput (Toxalasma lividus), and clubshell (Pleurobema clava) fell completely outside of protected areas. Similar differences among fishes, mollusks, and insects were evident at the landscape scale. Clubshell occurred within watersheds that entirely lack protected areas.

Comparisons among rare species from different habitat types showed that coverage of aquatic species within protected areas was lower than that of wetland or terrestrial species. At the local scale, significant differences occurred among habitat groups in the frequency of both highly protected $\left(F_{2,53}=5.91, p=0.005\right)$ and unprotected $\left(F_{2,53}=11.66, p<0.001\right)$ populations. Aquatic species were least likely to be highly protected (Fig. 5a) and most likely to be unprotected (Fig. 5a). Terrestrial species were the best protected, and wetland species were intermediate in frequency of high protection. Differences in the likelihood of being unprotected persisted among habitat types at the landscape scale $\left(F_{2,53}=3.41\right.$, $p=0.040$ ). Aquatic species occurred more frequently in unprotected landscapes than terrestrial species, and wetland species were intermediate.

\section{Discussion}

We found that aquatic features of Michigan's inland waters are unevenly represented within the state's network 
(a)
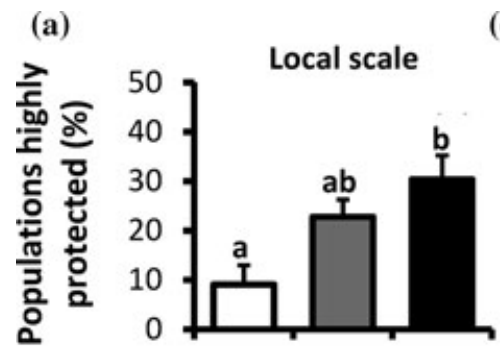

(b)

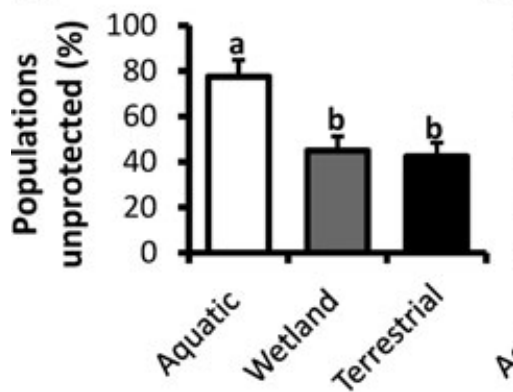

(d)
Landscape scale
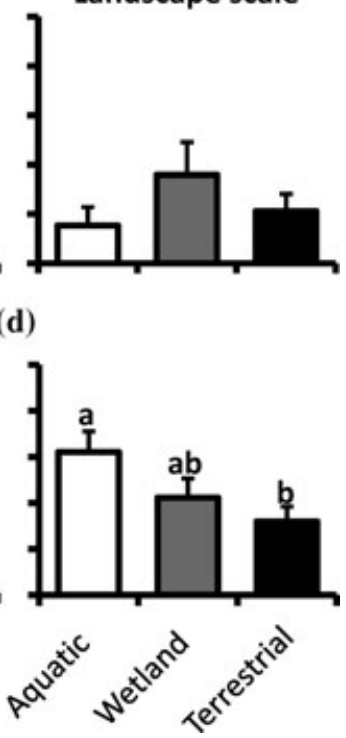

Figure 5. Occurrence of rare aquatic, wetland, and terrestrial species within protected areas in Michigan. Bars indicate mean (SE) across species of the proportion of populations that were (a) well protected (>95\% within GAP 1-3 lands [see Fig. 1 for definitions]) at the local scale, (b) poorly protected $(<20 \%)$ at the local scale, (c) well protected at the landscape scale ( $>70 \%$ ), and (d) poorly protected at the landscape scale $(<10 \%)$. The analysis includes 16 aquatic, 18 wetland, and 22 terrestrial species. Letters indicate significant differences between habitat types with Tukey's post hoc tests $(\alpha=0.05)$.

of protected areas. Inclusion of wetlands within protected areas was higher than would be expected if protected areas were distributed at random, but representation of riparian habitats within GAP 1-3 lands was considerably lower than null expectations. Protection of groundwater recharge was slightly greater than random, but the region of peak recharge lies largely outside protected areas. Existing protected areas provided substantially less coverage of rare aquatic species than of rare terrestrial species, which themselves were not especially well represented. Such uneven coverage of aquatic conservation features indicates terrestrial reserve networks do not offer proportional protection of freshwater ecosystems. Although each of the specific patterns reported must be interpreted cautiously in light of the limited resolution of the data and the assumptions required for analysis, Michigan represents a best-case scenario for the quality and variety of spatial data on aquatic species and ecosystems. Thus, we believe our overall conclusions are likely to be robust to limitations of the data and our analytical procedures and may be broadly representative of patterns in other U.S. states.

The relatively high representation of wetlands we found is consistent with the notion that historically, government designation of parks and reserves has favored areas that are less attractive for agriculture and other economic uses (approximately 25\% of historic Michigan wetlands have been converted). More recently, their importance to wildlife, growing recognition of ecosystem services that wetlands provide, and their generally lower economic value have encouraged purchase of wetlands for wildlife conservation (e.g., Shiawassee National Wildlife Refuge, Saginaw Bay EDU). Lowland shrubs, the only wetland type not represented at levels higher than anticipated, included some of the more common wetland communities (Kost et al. 2007). Moreover, many wetland community types of greatest conservation concern (e.g., fens) were within the well-represented emergent wetland type. Thus, the overall outlook for wetland conservation in Michigan is relatively favorable.

In contrast to wetlands, protection of riparian corridors along rivers fell markedly below expected levels for GAP 1-3 lands. The disproportionately low representation of riparian zones along larger rivers is not surprising given the long history of riverside settlement, commerce, and agriculture, but the poor representation of headwater streams was surprising. Headwater streams represent a large majority of total river length, and riparian protection along them is a pillar of river and forest management (Young 2000; Olson et al. 2007) because they play an essential role in conserving biodiversity and ecosystem processes (Meyer et al. 2007). Despite the low proportion of riparian coverage in GAP 3 lands, the higher levels of riparian coverage in GAP 1-2 lands suggests that the conservation community has made progress in establishing streamside habitat as a priority for protection. This is primarily the result of the National Wild and Scenic Rivers program, which mandates more-restrictive management (i.e., GAP 1 or 2) on what were previously GAP 3 public lands. In addition, the Michigan Natural Rivers Program, which provides riparian protection on private lands (similar to GAP 3), has substantially increased riparian protection levels in many EDUs.

Our analysis of groundwater recharge within conservation lands provides several insights. First, at statewide and watershed scales, protection of a larger fraction of groundwater recharge flux than land area indicates that protected areas often feature above-average recharge (Fig. 4). This conclusion must be tempered by the fact that modeled estimates of groundwater recharge are affected by land-use patterns, which in turn reflects protected-area status. Especially in southern Michigan, where agricultural and urban development are dominant, above-average recharge in protected areas likely reflects reduced recharge in unprotected areas. Nevertheless, the overall outlook for conserving groundwater recharge in Michigan appears better than for riparian habitats or aquatic species. 
Our groundwater recharge analysis demonstrates the potential for conservation planning to include protection of the processes that are requisite to long-term conservation of target species and ecosystem types. In the case of groundwater recharge, a variety of major threats are already known (e.g., impermeable surfaces, engineered drainage systems, stream channelization), which enables investments in prevention and remediation that target lands with high recharge rates, particularly when the resulting groundwater sustains unusually sensitive species and ecosystems. Given the importance of groundwater inputs to adjacent rivers, efforts to conserve the concentration of high groundwater recharge areas in the northern Lower Peninsula should be considered.

Poor representation of aquatic species is consistent with the results of previous studies (e.g., Keith 2000), but we are among the first to compare protection of rare aquatic and terrestrial species directly. Our results strongly suggest that, regardless of spatial scale, the current protected-area network serves terrestrial and wetland species better than aquatic species (Fig. 5). This pattern is intriguing given that most of Michigan's protected lands were not selected on the basis of rare species distributions, whether terrestrial or aquatic. It is unlikely that sampling effort between protected and unprotected lands differed, which created a bias in favor of representation of terrestrial species because the distributions of globally rare species have been studied intensively on public and private lands (e.g., Fettinger 2005).

The lack of protection for globally rare aquatic species in Michigan merits immediate action to minimize risk of extirpations. The four fish and seven mussel species considered rare may be in particular jeopardy because they are distributed primarily in the poorly protected Lower Peninsula. In contrast, the five rare beetles and dragonflies are found in the well-protected Upper Peninsula and northern Lower Peninsula EDUs. Thus, existing GAP 1-3 lands appear to benefit rare insects more than fishes or mussels, but these differences among taxonomic groups arise from biogeography rather than inherent differences between taxa (Supporting Information).

Like previous analyses of protected areas in the United States (e.g., Dietz \& Czech 2005), our results highlight the prevalence of GAP 3 lands within the protected area network. Although $21.8 \%$ of Michigan's area is managed with conservation as a broad goal (GAP 1-3), only $2.2 \%$ is assured of long-term, stringent protection (GAP 1-2). It is difficult to assess the true conservation value of the $19.6 \%$ of Michigan's lands that are GAP 3 . The GAP 3 lands are managed for multiple uses, including resource extraction; therefore, conservation constitutes only one of many factors influencing their management. Recent legislation in Michigan provides one model for strengthening management of GAP 3 lands for conservation. State law (Public Act 125 of 2004) now requires that state forests be certified under the Sustainable Forestry Ini- tiative (SFI) and the Forest Stewardship Council (FSC). These certifications require periodic reviews of ecological sustainability, including protection of rare species and sensitive habitats.

For all protected lands, there is also a risk that management for conservation will be designed from a terrestrial perspective, allowing inadvertent acceptance of activities harmful to aquatic biodiversity. For instance, limited resource extraction or road construction on GAP 3 lands that might be acceptable from a terrestrial standpoint could have strong detrimental effects on rivers and lakes. Even GAP 1 lands do not always ensure protection of aquatic features. Activities such as incompatible fish stocking or diking and water-level manipulations for waterfowl management are routine practices (Knapp \& Matthews 2000; Mayer 2005). Thus, it is imperative that the impacts on aquatic ecosystems be accounted for in management of all lands.

\section{Broader Implications}

The inadequacy of Michigan's protected-area network in representing important freshwater conservation features underscores the need for freshwater-specific planning and management. Although protected areas in Michigan and elsewhere generally have been acquired for purposes other than aquatic conservation, these lands can serve as substantial building blocks for a more-comprehensive strategy. Specifically, strategic selection of additional protected areas should target deficiencies in the coverage of freshwater features within existing terrestrial reserves (Frissell 1997; Abell et al. 2007) and maximize returns on investment by designing new reserves to protect terrestrial and aquatic features simultaneously (e.g., Wuethrich 2000; Roux et al. 2008). Given the scarcity of funds available for establishing new protected areas, upgrading certain GAP 3 lands to GAP 1-2 could also yield enhanced protection at minimal cost (Dietz \& Czech 2005). Approaches that protect high-value areas without directly purchasing them (e.g., easements, U.S. Department of Agricultural [USDA] conservation programs, zoning regulations) are promising because they are less expensive. Drawbacks to alternative protection strategies generally include lack of management flexibility, lack of permanence (e.g., some USDA programs), and scattered implementation due to variation in interest (e.g., USDA programs) or local political feasibility (e.g., zoning). But these strategies will need to be used, along with strategic land purchases, to better represent aquatic features at a regional scale. Our results demonstrate that both the federal Wild and Scenic Rivers Program and the Michigan Natural Rivers Program exemplify successful strategies for enhancing long-term protection in the absence of conservation-oriented land ownership. 
We recognize that land protection alone may not ensure the conservation of aquatic features. The configuration of protected areas is critical for freshwater conservation. Existing freshwater protected areas often fail because they occur downstream from disturbed lands (Mancini et al. 2005; Abell et al. 2007; Roux et al. 2008), because rivers along reserve borders receive protection on only one side (Duckworth et al. 1998; Thieme et al. 2007; Roux et al. 2008), or because they conserve a small, fragmented area that lacks sufficient connectivity to a broad suite of habitats (Pringle 2001). In addition, other threats such as invasive species and dams may override the benefits of land protection (Saunders et al. 2002; Abell et al. 2007; Sowa et al. 2007). Addressing such threats requires combining land protection with specific strategies like streamflow restoration and integrated watershed management (Abell et al. 2007; Higgins et al. 2007).

Our approach illustrates the value of parallel conservation assessments of habitats, species, and ecosystem processes. It is also among the first broad-scale, quantitative assessments of the role of protected areas in conserving the fundamental ecosystem process of groundwater recharge and demonstrates the need to look beyond traditional conservation targets in protected-areas analyses. Many of the types of geospatial data that we used are widely available; therefore, similar analyses should be feasible in other regions of the world. Although quantifying the coverage of freshwater features provides only an incomplete picture of actual conservation, our results represent a first step in understanding how best to build on existing terrestrial reserve networks to enhance freshwater conservation.

\section{Acknowledgments}

We thank S. Sobaski for GIS assistance, R. MacLeod for advice on data layers, N. Sindorf for the ecoregional protected area data, K. Kowalski for wetlands advice, and Michigan Natural Features Inventory for their long-term efforts to collect and manage data on rare species. The manuscript was improved by comments from C. Frissell, D. Ewert, C. Hall, J. Higgins, M. Koury, S. Sowa, and two anonymous reviewers. P.B.M. was supported by a Smith Fellowship. M.E.H. and P.J.D were supported by The Nature Conservancy's Great Lakes Fund for Partnership in Conservation Science and Economics.

\section{Supporting Information}

Percentages of terrestrial area protected within freshwater ecoregions (Appendix S1), a list of globally rare species used in analyses (Appendix S2), and levels of protection for fish, insects, and mollusks (Appendix S3) are available as part of the online article. The authors are responsible for the content and functionality of these materials. Queries (other than absence of the material) should be directed to the corresponding author.

\section{Literature Cited}

Abell, R., J. D. Allan, and B. Lehner. 2007. Unlocking the potential of protected areas for freshwaters. Biological Conservation 134:48-63.

Abell, R., et al. 2008. Freshwater ecoregions of the world: a new map of biogeographic units for freshwater biodiversity conservation. BioScience 58:403-414.

Aichele, S. S. 2005. Estimating shallow ground-water recharge in Michigan. Page 3 in B. P. Neff, A. R. Piggott, and R. A. Sheets. Estimation of shallow ground-water recharge in the Great Lakes Basin. Scientific investigations report 2005-5284. U.S. Geological Survey, Reston, Virginia.

Allan, J. D., and M. M. Castillo. 2007. Stream ecology-structure and function of running waters. 2nd edition. Springer-Verlag, Dordrecht, The Netherlands.

Allan, J. D., and A. S. Flecker. 1993. Biodiversity conservation in running waters. BioScience 43:32-43.

Comer, P. J., D. A. Albert, H. A. Wells, B. L. Hart, J. B. Raab, D. L. Price, D. M. Kashian, R. A. Corner, and D. W. Schuen. 1995. Michigan's presettlement vegetation, as interpreted from the General Land Office Surveys 1816-1856 (digital map). Michigan Natural Features Inventory, Lansing, Michigan.

Convention on Biological Diversity (CBD). 2006. Decision VII/4: biological diversity of inland water ecosystems. VII/4. CBD, Montreal.

Dahl, T. E . 1990. Wetlands losses in the United States 1780's to 1980's. U.S. Fish and Wildlife Service, Washington, D.C.

Dietz, R. W., and B. Czech. 2005. Conservation deficits for the continental United States: an ecosystem Gap Analysis. Conservation Biology 19:1478-1487.

DU (Ducks Unlimited) and TNC (The Nature Conservancy). 2007. Conservation and recreation lands (CARL). DU, Ann Arbor, Michigan. Available from http://www.ducks.org/Conservation/GLARO/ 3750/GISCARL.html (accessed November 2007).

Duckworth, J. W., R. J. Timmins, and T. D. Evans. 1998. The conservation status of the river lapwing Vanellus duvaucelii in southern Laos. Biological Conservation 84:215-222.

Dudgeon, D., et al. 2006. Freshwater biodiversity: importance, threats, status and conservation challenges. Biological Reviews 81:163-182.

Forest Ecosystem Management Assessment Team (FEMAT). 1993. Forest ecosystem management: an ecological, economic and social assessment. Report of the Forest Ecosystem Management Assessment Team. 1993-793-071. U.S. Government Printing Office, Washington, D.C.

Fettinger, J. L. 2005. Comprehensive population and habitat surveys for the Karner blue (Lycaeides melissa samuelis) in Michigan: final report for the Michigan Dept. of Natural Resources. Report 2005-08. Michigan Natural Features Inventory, Lansing, Michigan.

Frissell, C. A. 1997. Ecological principles. Pages 96-115 in J. E. Williams, C. A. Wood, M. P. Dombeck, editors, Watershed restoration: principles and practices. American Fisheries Society, Bethesda, Maryland.

Gregory, S. V., F. J. Swanson, A. McKee, and K. W. Cummins. 1991. An ecosystem perspective of riparian zones: focus on links between land and water. BioScience 41:540-551.

Higgins, J., R. Unnasch, and C. Supples. 2007. Ecoregional status measures version 1.0: Framework and technical guidance to estimate effective conservation. The Nature Conservancy, Arlington, Virginia.

Keith, P. 2000. The part played by protected areas in the conservation of threatened French freshwater fish. Biological Conservation 92:265-273.

Knapp, R. A., and K. R. Matthews. 2000. Non-native fish introductions and the decline of the mountain yellow-legged frog from within protected areas. Conservation Biology 14:428-438. 
Kost, M. A., D. A. Albert, J. G. Cohen, B. S. Slaughter, R. K. Schillo, C. R. Weber, and K. A. Chapman. 2007. Natural communities of Michigan: classification and description. Report 2007-21. Michigan Natural Features Inventory, Lansing, Michigan.

Mancini, L., P. Formichetti, A. Anselmo L. Tancioni, S. Marchini, and A. Sorace. 2005. Biological quality of running waters in protected areas: the influence of size and land use. Biodiversity and Conservation 14:351-364.

Mayer, T. D. 2005. Water-quality impacts of wetland management in the lower Klamath National Wildlife Refuge, Oregon and California, USA. Wetlands 25:697-712.

Meyer, J. L., D. L. Strayer, J. B. Wallace, S. L. Eggert, G. S. Helfman, and N. L. Leonard. 2007. The contribution of headwater streams to biodiversity in river networks. Journal of the American Water Resources Association 43:86-103.

Michigan Center for Geographic Information (MCGI). 2007. Hydropoly_miv7b. Michigan Department of Information Technology, Lansing. Available from http://www.mcgi.state.mi.us/mgdl/? action $=$ thm (accessed July 2007).

Michigan Department of Natural Resources (DNR). 2003. Integrated forest monitoring assessment and prescription (IFMAP)/GAP Lower Peninsula land cover. Remote sensing image. Time period of content 1997-2001. DNR, Lansing. Available from http://www. mcgi.state.mi.us (assessed July 2007).

Michigan Natural Features Inventory (MNFI). 2008. Statewide Biotics 4 database. MNFI, Lansing, Michigan.

Miller, M. W. and T. D. Nudds. 1996. Prairie landscape change and flooding in the Mississippi River Valley. Conservation Biology 10:847-853.

Mitsch, W. J., and J. G. Gosselink. 2007. Wetlands. John Wiley \& Sons, Hoboken, New Jersey.

Noss, R. F. 1987. From plant communities to landscapes in conservation inventories: a look at The Nature Conservancy (USA). Biological Conservation 41:11-37.

Olson, D. L., P. D. Anderson, C. A. Frissell, H. H. Welsh Jr., and D. F. Bradford. 2007. Biodiversity management approaches for streamriparian areas: perspectives for Pacific Northwest headwater forests, microclimates, and amphibians. Forest Ecology and Management 246:81-107.

Poff, N. L., J. D. Allan, M. B. Bain, J. R. Karr, K. L. Prestegaard, B. D. Richter, R. E. Sparks, and J. C. Stromberg. 1997. The natural flow regime: a paradigm for river conservation and restoration. BioScience 47:769-784.

Pringle, C. M. 2001. Hydrologic connectivity and the management of biological reserves: a global perspective. Ecological Applications 11:981-998.
Ramsar Bureau. 2009. Strategic framework for the list of Wetlands of International Importance of the Convention on Wetlands. Ramsar, Gland, Switzerland. Available from http://195.143.117.139/ key_guide_list2009_e.htm (accessed October 2009).

Ricciardi, A., and J. B. Rasmussen. 1999. Extinction rates of North American freshwater fauna. Conservation Biology 13:12201222.

Roux, D. J., et al. 2008. Designing protected areas to conserve riverine biodiversity: lessons from a hypothetical redesign of the Kruger National Park. Biological Conservation 141:100-117.

Saunders, D. L., J. J. Meeuwig, and A. C. J. Vincent. 2002. Freshwater protected areas: strategies for conservation. Conservation Biology 16:30-41.

Scott, J. M., et al. 1993. Gap analysis: a geographic approach to protection of biological diversity. Wildlife Monographs 123:1-41.

Scott, J. M., F. W. Davis, R. G. McGhie, R. G. Wright, C. Groves, and J. Estes. 2001. Nature reserves: do they capture the full range of America's biological diversity? Ecological Applications 11:9991007.

Seaber, P. R., F. P. Kapinos, and G. L. Knapp. 1987. Hydrologic unit maps. Water supply paper 2294. U.S. Geological Survey, Denver, Colorado.

Sowa, S. P., G. Annis, M. E. Morey, and D. D. Diamond. 2007. A Gap analysis and comprehensive conservation strategy for riverine ecosystems of Missouri. Ecological Monographs 77:301-334.

The Nature Conservancy. 2001. Aquatic ecoregional planning in the U.S. portion of the Great Lakes watershed. The Nature Conservancy, Chicago.

Thieme, M., B. Lehner, R. Abell, S. K. Hamilton, J. Kellndorfer, G. Powell, and J. C. Riveros. 2007. Freshwater conservation planning in datapoor areas: an example from a remote Amazonian basin (Madre de Dios River, Peru and Bolivia). Biological Conservation 135:484501.

U.S. Geological Survey. 1999. Standards for national hydrography dataset. U.S.Geological Survey, Reston, Virginia. Available from http://nhd.usgs.gov/ (accessed July 2007).

Young, K. A. 2000. Riparian zone management in the Pacific Northwest: who's cutting what? Environmental Management 26:131-144.

World Database on Protected Areas (WDPA). 2004. World database on protected areas. WDPA, Washington, D.C.

Wuethrich, B. 2000. When protecting one species hurts another. Science 289:383-385.

Zorn, T. G., P. W. Seelbach, and M. J. Wiley. 2002. Distributions of stream fishes and their relationship to stream size and hydrology in Michigan's Lower Peninsula. Transactions of the American Fisheries Society 131: 70-85.

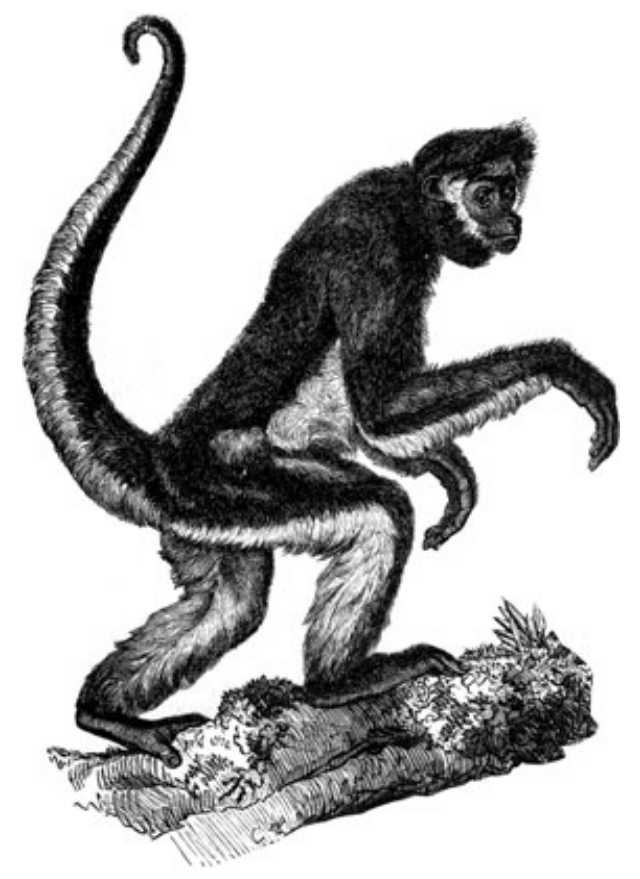

